\title{
TREATMENT OF SERUM WITH SUPERNATANTS FROM CULTURES OF CANDIDA ALBICANS REDUCES ITS SERUM-DEPENDENT PHAGOCYTOSIS
}

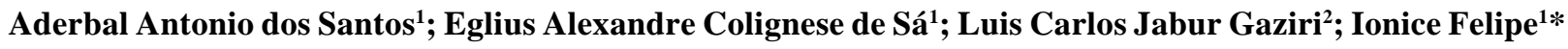 \\ ${ }^{1}$ Departamento de Ciências Patológicas, ${ }^{2}$ Departamento de Ciências Fisiológicas, Universidade Estadual de Londrina, \\ Londrina, PR, Brasil
}

Submitted: April 05, 2001; Returned to authors for corresction: September 26, 2001; Approved: January 02, 2002

\begin{abstract}
Candida albicans is a potent activator of the complement system, and heat labile opsonins produced by activation of $\mathrm{C} 3(\mathrm{C} 3 \mathrm{~b}$ and $\mathrm{iC} 3 \mathrm{~b}$ ) enhance phagocytosis of $C$. albicans mediated by complement receptors. In this study we treated mouse serum with supernatants from cultures of a protease producer strain of $C$. albicans and evaluated the ability of this serum to enhance phagocytosis of $C$. albicans. Cell-free supernatants from cultures of $C$. albicans were concentrated 5 fold and added to mouse serum for $30 \mathrm{~min}$ at $37^{\circ} \mathrm{C}$, before using this serum for opsonization of glutaraldehyde-fixed yeast cells. We observed that normal mouse serum increased about 3 fold the phagocytosis of $C$. albicans by mice peritoneal macrophages, whereas supernatant-treated serum did not increase phagocytosis. This effect of supernatants on serum was prevented by addition of pepstatin $(5 \mu \mathrm{g} / \mathrm{ml}$; an inhibitor of $C$. albicans acid proteases) to the medium. Serum treated with supernatants from cultures of a protease-deficient mutant of $C$. albicans also increased about 3 fold phagocytosis of the yeast. These results suggest that a protease produced by $C$. albicans causes proteolysis of serum opsonins, thereby reducing the phagocytosis of the yeast.
\end{abstract}

Key words: Candida albicans, phagocytosis, proteinase

\section{INTRODUCTION}

Systemic candidiasis and chronic mucocutaneous candidiasis are common clinical forms of Candida albicans infection in the compromised host $(1,29)$. C. albicans is now the fourth leading cause of nosocomial bloodstream infections (10), and disseminated candidiasis has increased dramatically as a result of widespread use of chemotherapeutic drugs, indwelling catheters, and certain kinds of surgical and other medical procedures (5). The increase in clinical importance of C. albicans and diagnostic, treatment, and prevention enigmas associated with disseminated candidiasis, are reasons to gain an understanding of the interaction between this microorganism and host defense systems.

Several authors have suggested that proteases secreted by C. albicans act as virulence factors; such proteases seem to facilitate adherence $(2,13)$ and growth $(30)$ of $C$. albicans, and seem to increase its invasiveness of epithelial and other tissues (2). Moreover, proteinase antigen was detected on blastoconidia cells after $30 \mathrm{~min}$ in culture medium containing $10 \%$ fetal calf serum and after $30 \mathrm{~min}$ of co-incubation with phagocytes (3). In a previous work (4), we observed a significant reduction of the viability of macrophages coincubated with $C$. albicans for 30 min, at a time when the phagocytosed yeast had not yet formed germ tubes inside the macrophages. Furthermore, incubation of macrophages with supernatants from cultures of $C$. albicans also reduced their viability. Addition of albumin or pepstatin to the medium counteracted this cytotoxic effect of supernatants, leading us to suggest that albumin either acted as a substrate for the proteases, or blocked the action of proteases by forming a complex with them or by binding to the surface of macrophages.

\footnotetext{
* Corresponding author. Mailing address: Departamento de Ciências Patológicas, Universidade Estadual de Londrina, 86051-970, Londrina, PR, Brasil. Phone: (+5543) 371 4267, Fax: (+5543) 371 4207. E-mail ionice@uel.br
} 
In this study, we tested the hypothesis that a protease present in supernatants from $C$. albicans culture could reduce the opsonic activity of serum, and consequently decrease phagocytosis of $C$. albicans via complement receptors.

\section{MATERIALS AND METHODS}

\section{Candida albicans culture}

Candida albicans strain 577 was maintained at room temperature in Sabouraud dextrose agar. This strain was isolated from a patient with mucocutaneous candidiasis and kindly provided by Prof. Luis Rodolfo Travassos (Escola Paulista de Medicina, São Paulo, Brazil). For phagocytosis experiments, ten loopfulls of this culture were aseptically transferred to an Erlenmeyer flask containing $100 \mathrm{ml}$ Sabouraud dextrose and the yeast was grown for $24 \mathrm{~h}$ at $25^{\circ} \mathrm{C}$. Yeast cells were then harvested by centrifugation ( $150 \mathrm{X} \mathrm{G}$ for $5 \mathrm{~min}$ ), washed three times in sodium phosphate buffered saline (PBS; $\mathrm{pH} 7$ ), fixed overnight in $1 \%$ glutaraldehyde at $4^{\circ} \mathrm{C}$, and washed ten times in PBS. More than $95 \%$ of harvested cells were in the yeast form, which were maintained at $-4^{\circ} \mathrm{C}$ for the phagocytic assays. A proteinase deficient mutant of $C$. albicans (strain FCF14-1) was also used in this work, and it was grown as described above; this strain was a kind gift from Prof. M.T. Shimizu (Department of Pathology, Universidade Estadual Paulista "Julio de Mesquita Filho” UNESP, São José dos Campos, SP, Brazil).

\section{Preparation of $C$. albicans supernatant}

C. albicans cells were washed in PBS and suspended at $10^{8}$ cells/ml in RPMI medium (Sigma Chem Co, St. Louis, MO) and incubated at $37^{\circ} \mathrm{C}$ for $2 \mathrm{~h}(4)$. Cell - free supernatant from this culture was obtained by centrifugation at $150 \mathrm{X} \mathrm{G}$ for $10 \mathrm{~min}$ at $4^{\circ} \mathrm{C}$, followed by passage through $0.45 \mu \mathrm{m}$ filters (Millipore Corp, Boston MA). The supernatant was concentrated about 5-fold by ultrafiltration with PM 10 diaflo membranes (Amicon Corp. Lexington, MA) and used immediately.

\section{Sera}

Normal mouse serum (NMS) was obtained from Swiss mice. The mice were exsanguinated through the brachial plexus under ether anesthesia, and whole blood was allowed to clot for 60 min on ice and centrifuged at $150 \mathrm{X} \mathrm{G}$ for $10 \mathrm{~min}$ at $4^{\circ} \mathrm{C}$. Serum was removed and used immediately for opsonization of $C$. albicans. As a control, serum was inactivated by heating at $56^{\circ} \mathrm{C}$ for $30 \mathrm{~min}$ (HIMS).

\section{Opsonization of Candida albicans}

Opsonization was performed by adding $100 \mu \mathrm{l}$ of NMS to $10^{7}$ C. albicans cells in $900 \mu \mathrm{l}$ of RPMI medium containing $1 \%$ albumin for $30 \mathrm{~min}$ at $37^{\circ} \mathrm{C}$. NMS used for opsonization was either, a) positive control ( $250 \mu \mathrm{l}$ NMS plus $750 \mathrm{ml}$ RPMI), b) NMS pretreated with $C$. albicans supernatant, or c) with NMS pretreated supernatant concentrated 5 fold through a membrane concentrator d) NMS pretreated with supernatant concentrated 5 fold and then diluted 5 fold e)NMS diluted in RPMI to contain a final concentration of either $2.5 \mu \mathrm{g}$ or $5 \mu \mathrm{g}$ of pepstatin (Sigma Chem Co) per ml. All NMS sample dilutions were equivalent to $250 \mu \mathrm{l}$ of NMS plus $750 \mu \mathrm{l}$ of RPMI.

\section{Phagocytosis assay}

The peritoneal exudate from Swiss mice pretreated with $3 \%$ thioglycollate medium was collected with 4ml RPMI medium as described previously ( 3 ). The cells $\left(2 \times 10^{5}\right)$ were allowed to adhere to coverslips for $1 \mathrm{~h}$ at $37^{\circ} \mathrm{C}$ and nonadherent cells were removed. One $\mathrm{ml}$ of $C$. albicans $\left(10^{7}\right)$ was added to the monolayer of peritoneal macrophages and incubated at $37^{\circ} \mathrm{C}$ for $1 \mathrm{~h}$. The phagocytic index was evaluated by counting 200 macrophages per each sample in a Nikon microscope after staining with hematoxylin-eosin. The phagocytic index (PI) was calculated as the percent of macrophages containing one or more yeast cells times the mean number of yeast per macrophage (6).

\section{Detection of Protease production by Candida albicans}

Briefly, protease secretion was tested by applying disks of filter paper containing adsorbed $C$. albicans onto basic culture medium plates; presence of a clear halo around the filter paper disks, after staining with amido black (1\%, Sigma), reveals degradation of albumin. Basic culture medium according Shimizu et al. (27), contained $2 \mathrm{~g}$ of sucrose ( Merck, Germany), 0.3g sodium nitrate (Merck), 0.1g dibasic potassium phosphate (Merck), 0.05g magnesium phosphate (Merck), $0.05 \mathrm{~g}$ potassium chloride (Merck), 0.001g ferrous sulfate (Merck) and 1.5g agar (Difco), made up to $100 \mathrm{ml}$ with water. The final $\mathrm{pH}$ of the medium was 3.5. Gentamicin $(80 \mu \mathrm{g} / \mathrm{ml})$ and albumin $(1 \%$ final concentration) were added to the cooled medium; albumin ( $5 \%$ bovine serum albumin, Fraction V; Sigma) was sterilized by ultrafiltration $(0.20 \mu \mathrm{m}$ filters, millipore). The plates were incubated overnight at $37^{\circ} \mathrm{C}$ to test sterility. C. albicans grown as described above was adsorbed on sterile disks of filter paper containing chloramphenicol, and these disks were applied onto the plates, which were then incubated for one week at $37^{\circ} \mathrm{C}$.

\section{Statistics}

For statistics the program GB-STAT (Dynamic Microsystems, Silver Spring, MD) was used; significance of the difference between means was evaluated by Student's t test.

\section{RESULTS}

Opsonization of $C$. albicans with NMS caused an increase of about 3 fold on its phagocytosis as compared to C. albicans pre-incubated in RPMI . However, treatment of NMS with supernatant of $C$. albicans culture abolished this serum- 
dependent increase of phagocytosis. Heat-inactivated serum was also ineffective in increasing yeast phagocytosis (Fig. 1).

This reduction of the opsonic activity of the serum by supernatants from $C$. albicans cultures was dose-dependent and was counteracted by pepstatin. Although pepstatin at a concentration of $2.5 \mu \mathrm{g} / \mathrm{ml}$ did not block completely this effect of supernatants, NMS treated with supernatants in a medium containing $5 \mu \mathrm{g} / \mathrm{ml}$ of pepstatin presented no reduction of opsonic activity. Furthermore, NMS treated with supernatants from cultures of a protease deficient mutant of $C$. albicans also presented no reduction of opsonic activity (Fig. 2).

Cultures of $C$. albicans employed in these experiments were routinely applied onto the basic medium plates for detection of protease secretion, and confirmed that the two strains maintained their characteristics concerning protease secretion during the experiments, that is, one strain was protease producer and the other was protease deficient (Fig. 3).

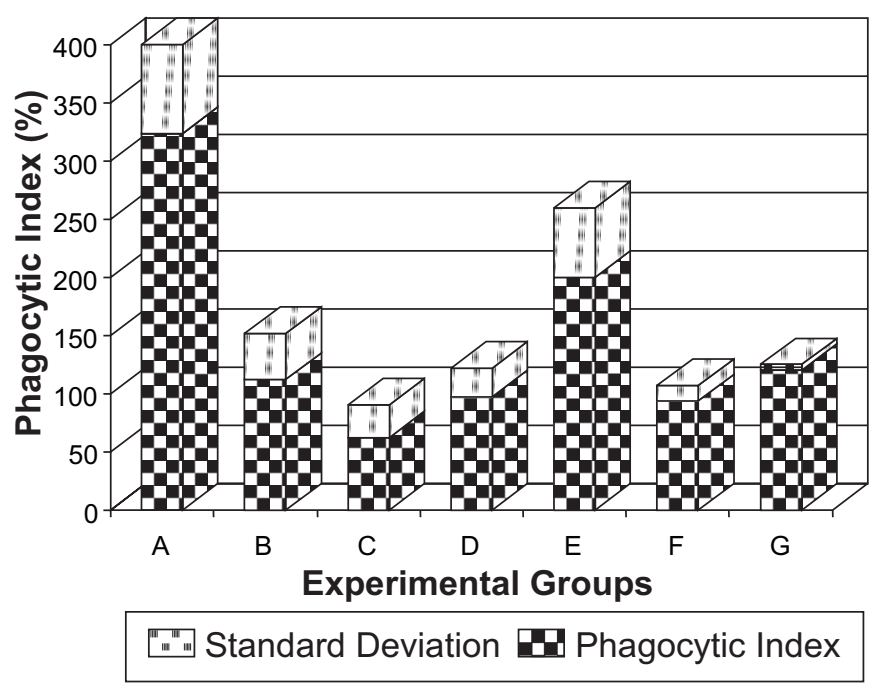

Figure 1. Effect of supernatants from Candida albicans cultures on the opsonic activity of normal mouse serum (NMS) $C$. albicans were pre-incubated with: (A) $2.5 \%$ NMS; (B) NMS pretreated with supernatant; (C) NMS pretreated with supernatant concentrated 5 fold through a membrane concentrator; (D) NMS pretreated with supernatant concentrated 5 fold and then diluted 5 fold; (E) NMS pretreated with supernatant concentrated 5 fold and then diluted 10 fold; $(\mathrm{F})$ $2.5 \%$ heat-inactivated mouse serum; or (G) RPMI medium (negative control) for $15 \mathrm{~min}$ at $37^{\circ} \mathrm{C}$. These preparations of $C$. albicans were then co-incubated with mouse peritoneal macrophages adhered to coverslips for one hour at $37^{\circ} \mathrm{C}$ and the phagocytic index was determined. Results are expressed as the mean phagocytic index \pm SD for at least seven experiments; $p<$ 0.05 for A vs. any other experimental group and for B vs. C.

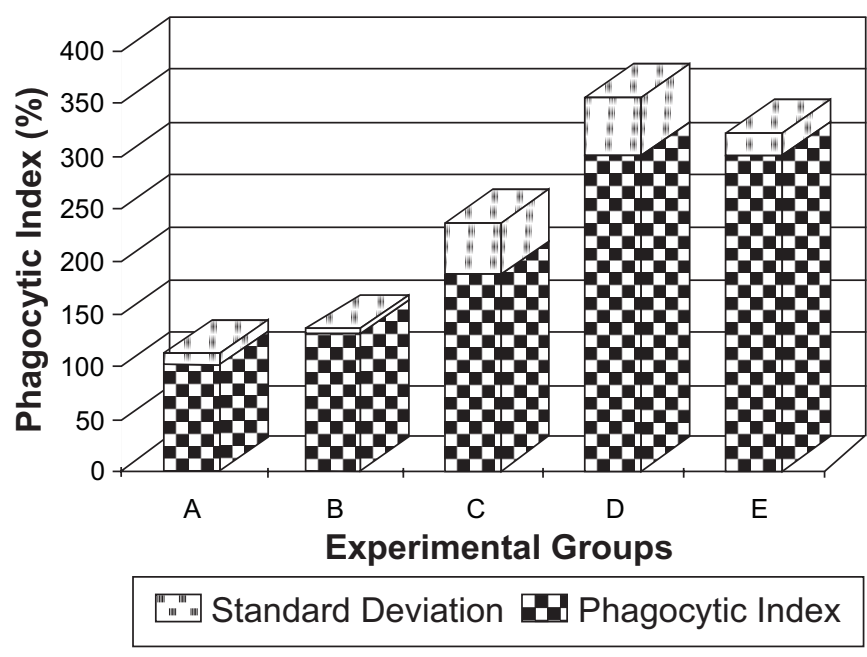

Figure 2. Inhibition by pepstatin of the effect of supernatants from Candida albicans cultures on the opsonic activity of normal mouse serum (NMS). (A) C. albicans pre-incubated with RPMI medium (negative control). (B) through (E), NMS pretreated with: (B) supernatant; (C) supernatant preincubated with pepstatin $\left(2.5 \mu \mathrm{g} \mathrm{ml}^{-1}\right)$; (D) supernatant preincubated with pepstatin $\left(5 \mu \mathrm{g} \mathrm{ml}^{-1}\right)$; (E) supernatant from cultures of a protease deficient mutant strain. C. albicans were opsonized for 15 min with those preparations of NMS and then co-incubated with mouse peritoneal macrophages for one hour at $37^{\circ} \mathrm{C}$. Results are expressed as the mean phagocytic index \pm SD for at least five experiments; $p<0.05$ for $\mathrm{D}$ or $\mathrm{E}$ vs. A or B.

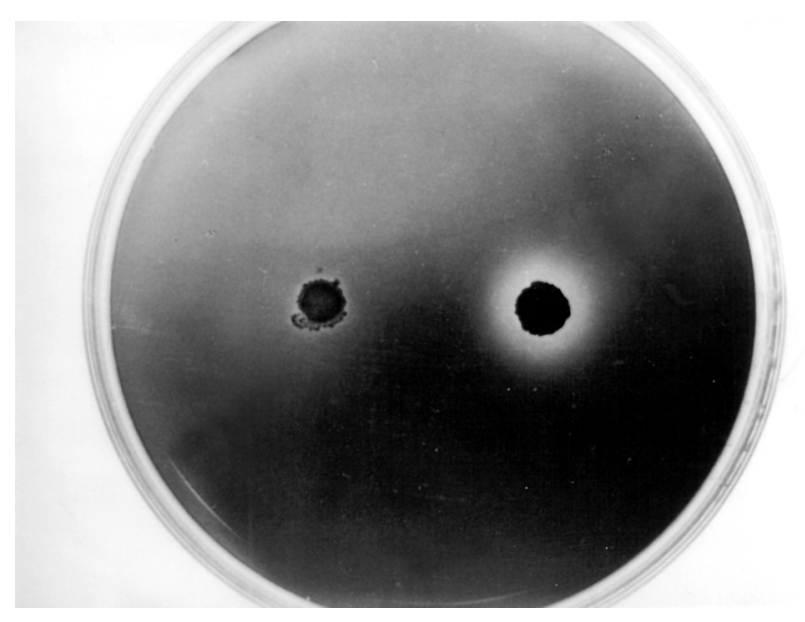

Figure 3. Proteinases production by $C$. albicans. 1- Colonies of $C$. albicans are on disks of filter paper at the center of the plate and a clear zone produced by degradation of albumin can be observed around strain 577 but not around strain FCF14-1. The undigested albumin has been precipitated with $2 \mathrm{~N}$ acetic acid and stained with a solution of amide-black (1\%). 


\section{DISCUSSION}

Studies employing experimental models of $C$. albicans infection show that the complement system plays an important role in resistance to disseminated candidiasis; for instance, guinea pigs treated with cobra venom factor, which reduces the amount of complement in the serum, have a higher rate of mortality than untreated animals in response to $C$. albicans infection (9). Analysis of the kinetics for activation and binding of $\mathrm{C} 3$ fragments to $C$. albicans blastoconidia showed very rapid deposition of $\mathrm{C} 3$ onto the yeast cells by classical pathway activation, and similar end results were also found, but with slower deposition of $\mathrm{C} 3$, by the alternative pathway $(16,17)$. Previous studies from our laboratory and by other investigators $(8,11,19,21,25)$ have demonstrated that opsonins from complement deposited on the surface of $C$. albicans can enhance its phagocytosis by polymorphonuclear neutrophils and by macrophages. In this study we observed a three fold increase of phagocytosis when $C$. albicans cells were opsonized with normal mouse serum, compared with phagocytosis in absence of serum, whereas heat-inactivated serum did not cause such an increase of phagocytosis. On the other hand, treatment of serum with supernatants from $C$. albicans caused a significant dose-dependent reduction of phagocytosis of yeast cells, that is, a reduction of the opsonic activity of serum. Addition of pepstatin, an inhibitor of $C$. albicans acid protease $(7,26)$, counteracted this reduction of serum opsonic activity by culture supernatants. Moreover, treatment of serum with supernatants from cultures of a protease deficient mutant did not reduce its opsonic activity. These results suggest that the observed reduction of opsonic activity was due to degradation of complement molecules by a protease present in the culture supernatants, and they are corroborated by a previous observation that supernatant from $C$. albicans culture break down complement $\mathrm{C} 3$ molecules and caused a clear reduction in the bactericidal activity of human serum against Escherichia coli (12).

C. albicans is considered the most virulent yeast in the genus Candida and can cause a variety of infections in humans and in animals $(7,22,28)$. In human immunodeficiency virus (HIV)-infected individuals, up to $90 \%$ suffer from mucosal candidiasis at least once in the course of their disease (15). It has been demonstrated that $C$. albicans isolates from HIVpositive group produced higher level of aspartyl proteinase compared with that of isolates from the control group, and were also less susceptible to the widely used azole antifungal agents ketoconazole and fluconazole (24). However, treatment with human immunodeficiency virus (HIV) proteinase inhibitors saquinavir and indinavir reduced virulence phenotype in experimental candidiasis (15). On the other hand, protease deficient mutants have lower virulence for mice than the protease producer parents $(14,18,28)$, supporting the evidence that proteases activity is one of the virulence factors. In agreement with these previous reports, we observed that supernatants from a protease deficient mutant of $C$. albicans did not reduce serum opsonic activity. Elimination of $C$. albicans from an infected host requires the cooperation of Th1 cells and phagocytes (31). Concanavalin-A is a lectin that by binding directly to $\mathrm{CD} 3$ or TCR on the surface of Th1 cells cause activation of these cells with release of cytokines such as interferon-g, interleukin-2 and tumor necrosis factor-a (23) and results from our laboratory showed that treatment with this immunomodulator is able to activate macrophages which were more efficient to phagocytose and to kill this strain of $C$. albicans compared to control macrophages $(8,20)$, avoiding the production of virulence factors by this pathogen. Because there is no evidence that activation of complement can lyse $C$. albicans, participation of opsonins from complement seems essential to facilitate ingestion of the pathogen by phagocytes and its possible killing. Therefore, these results suggest that proteases secreted by $C$. albicans can be a virulence factor that decreases serum opsonic activity, and consequently reduces phagocytosis via complement receptors, thereby facilitating $C$. albicans survival and its colonization of host tissues and organs, especially in immunocompromised patients.

\section{ACKNOWLEDGMENTS}

We are grateful to Vania Darc de Castro (Departamento de Ciências Patológicas, Universidade Estadual de Londrina) for technical assistance.

\section{RESUMO}

\section{Tratamento de soro com sobrenadante de cultura de} Candida albicans reduz a fagocitose soro-dependente

Candida albicans é um potente ativador do sistema complemento, e opsoninas lábeis ao calor produzidas por ativação de $\mathrm{C} 3$ (C3b e iC3b) aumentam a fagocitose de $C$. albicans mediada por receptores de complemento. Neste estudo, tratamos o soro de camundongo com sobrenadante de culturas de uma cepa de C. albicans produtora de proteases e avaliamos a capacidade deste soro reduzir a fagocitose de C. albicans. Sobrenadantes livres de células obtidos de cultura de $C$. albicans foram concentrados 5 vezes e adicionados ao soro de camundongo por 30 minutos a $37^{\circ} \mathrm{C}$, antes deste soro ser usado para opsonização de C. albicans na forma de levedura e fixadas em glutaraldeido. Nós observamos que soro normal aumentou 3 vezes a fagocitose de $C$. albicans por macófagos peritoneais, enquanto que o soro tratado com sobrenadante não aumentou a fagocitose. Este efeito do sobrenadante sobre o soro foi evitado por adição de pepistatina ( $5 \mu \mathrm{g} / \mathrm{ml}$; um inibidor de proteinase ácida) ao meio. 
Soro tratado com sobrenadantes de culturas de um mutante de $C$. albicans deficiente em produção de proteinase também aumentou em 3 vezes a fagocitose da levedura. Estes resultados sugerem que uma proteinase produzida por $C$. albicans causa proteólise de opsoninas do soro, desta maneira reduzindo a fagocitose da levedura.

Palavras-chaves: Candida albicans, fagocitose, proteinase

\section{REFERENCES}

1. Bodey, G.P.; Candidiasis in cancer patients. Amer. J. Med., 30: 1318, 1984.

2. Borg, M.; Rüchel, R.; Expression of extracellular acid proteinase by proteolytic Candida spp. during experimental infection of oral mucosa. Infect. Immun., 56: 626-631, 1988.

3. Borg, M.; Ruchel, R. Demonstration of fungal proteinase during phagocytosis of Candida albicans and Candida tropicalis. J. Med. Vet. Mycol., 28: 3-14, 1990.

4. De-Andrade, G.M.; Felipe, I. Evidence for the participation of proteinases released by Candida albicans in the early killing of peritoneal macrophages In Vitro. Brazilian J. Med. Biol. Res., 25: 167-174, 1992.

5. Denning, D.W.; Epidemiology and pathogenisis of systemic fungal infections in the immunocompromised host. J. Anti-Microb. Chemother., 28(Suppl.B): 1-16, 1991.

6. Drevets, D.A.; Campbell, P.A.; Role of complement and complement receptors type 3. In phagocytosis of Listeria monocytogenes by inflammatory mouse peritoneal macrophages. Infect. Immun., 59: 2645-2652, 1991.

7. Fallon, K.; Bausch, K.; Noonan, J.; Huguenel, E.; Tamburini, P.; Role of aspartic proteases in disseminated Candida albicans infection in mice. Infect. Immun., 65: 551-556, 1997.

8. Gaziri, G.; Gaziri, L.C.J.; Kikuchi, R.; Scanavacca, J.; Felipe, I. Phagocytosis of Candida albicans by concanavalin-A activated macrophages. Med. Mycol., 37: 195-200, 1999.

9. Gelfand, J.A.; Hurley, D.L.; Fauci, A.S.; Frank, M.M.; Role of complement in host defense against experimental disseminated candidiasis. J. Infect. Dis., 138: 9-16, 1978.

10. Jarvis, W.R. Epidemiology of nosocomial fungal infections, with emphasis on candida species. Clin. Infect. Dis., 20: 1526-1530, 1995.

11. Kagaya, K.; Fukazawa, Y.; Murine defense mechanism against Candida albicans infection, opsonization, phagocytes and intracellular killing of Candida albicans. Microbiol. Immun., 25: 807-818, 1981.

12. Kaminishi, H.; Miyaguchi, H.; Tamaki, T.; Suenaga, N. et al. Degradation of humoral host defence by Candida Albicans proteinase. Infect. Immun., 63: 984-988, 1995.

13. Klotz, S.A.; Drutz, D.J.; Harrison, J.L.; Huppert, M.; Adherence and penetration of vascular endothelium by Candida albicans yeast. Infect. Immun., 42: 374-384, 1983.
14. Kondoh, Y.; Shimizu, K.; Tanaka, K.; Proteinase production and pathogenicity of Candida albicans. Virulence for mice of Candida albicans strains of different proteinase activity. Microbiol. Immun. 31: 1061-1069, 1987.

15. Korting, H.C.; Schaller, M.; Eder, G.; Hamm, G.; Bohmer, U.; Hube, B. Effects of human immunodeficiency virus (HIV) proteinase ihibitors saquinavir and indinavir on in vitro activities of secreted aspartyl proteinase of Candida albicans isolates from HIV-infected patients. Antimicrob. A. Chemother., 43: 2038-2042, 1999.

16. Kozel, T.R.; Activation of the complement system by pathogenic fungi. Clinical Microbiol. Rev., 9: 34-46, 1996.

17. Kozel, T.R.; Weinhold, L.C.; Lupan, D.M.; Distinct characteristics of initiation of the classical and alternative complement pathways by Candida albicans. Infect. Immun., 64: 3360-3368, 1996.

18. Mac Donald, F.; Odds, F.C.; Virulence for mice of a proteinase secreting strain of Candida albicans and a proteinase deficient mutant. J. Gen. Microbiol., 129: 431-438, 1983.

19. Maródi, L.; Korchaki, H.M.; Johnston Jr, R.B.; Mechanisms of host defense against Candida species. I. Phagocytosis by monocytes and monocyte derived macrophages. J. Immunol., 146: 2783-2789, 1991.

20. Moresco, T.R.; Gaziri, L.C.J.; Yasumoto, Y.; Felipe, I. Phagocytic and candicidal activities of macrophages from lactating and adult mice pretreated with concanavalin-A. Med. Mycol. In press.

21. Morrison, R.P.; Cutler, J.E.; In vitro studies of the interaction of murine phagocytic cells with Candida albicans. J. Reticuloendothel. Soc., 29: 23-33, 1981.

22. Odds, F.C.; Candida infections; An overview. CRC Critic. Rev Microbiol., 15: 1-5, 1987.

23. Okamoto, T.; Kobayashi, T. Effects of concanavalin-A on cytokine mRNA expression in mouse liver. Jpn. J. Pharmacol., 75: 199-201, 1997.

24. Ollert, M.W.; Wende, C.; Gorlich, M.; Candice, G. et al. Increased expression of Candida albicans secretory proteinase, a putative viruence factor, isolates from human immunodefiency virus-positive patients. J. Clin. Microbiol., 33: 2543-2549, 1995.

25. Ray, T.L.; Wuepper, K.D. Activation of the alternative (properdin) pathway of complement by Ccadida albicans and related species. J. Invest. Dermatol., 67: 700-703, 1976.

26. Rich, D.H.; Bernatowicz, M.S.; Agarwal, N.S.; Kawai, M.; Salituro, F.G.; Inhibition of aspartic proteases by pepstatin and 3Methylstatine derivatives of pepstatatin. Evidence for collected substrate enzyme inhibition. Biochem., 24: 3165-3173, 1985.

27. Shimizu, M.T.; Jorge, A.O.C.; Unterkircher, C.S.; Fantinato, V.; Paula C.R. Hyalorunidase and Chondroitin sulphatase production by different species of candida. J. Med. Vet. Mycol., 33: 27-31,1995.

28. Shimizu, M.T.; Almeida, N.Q.; Fantinato, V.; Unterkircher, C.S.; Studies on hyaluronidase, chondroitin sulphatase, proteinase secreted by Candida species. Mycoses, 39: 161-167, 1996.

29. Stein, D.K.; Sugar, A.M.; Fungal infections in the immunocompromised host. J. Infec. Dis., 131: 688-691, 1989.

30. Tsuobi, R.; Kurita, Y.; Negi, M.; Ogawa, H.; A specific inhibitor of keratinolytic proteinase from Candida albicans could inhibit cell growth of Candida albicans. J. Infect. Dermatolol., 85: 438-440, 1985.

31. Vásquez Torres, A.; Balish, E.; Macrophages in resistance to candidiasis. Microbiol. Molec. Biol. Rev., 61: 170-192, 1997. 